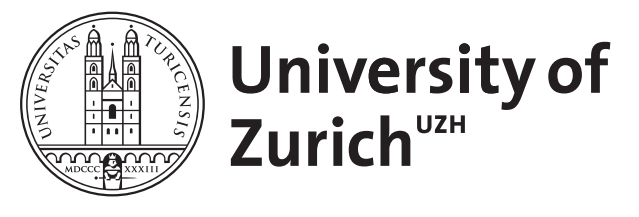

\title{
Shared ideas in Job and Deutero-Isaiah
}

\author{
Kwon, Jiseong James
}

\begin{abstract}
It has been suggested that the books of Job and of Deutero-Isaiah (Isaiah 40-55) have a variety of similarities in their linguistic features and common subject-matter and because of this, it has been argued that there is literary dependence or influence of one book upon the other. Although such an author-oriented approach, by which scholars explain similarities by the theory of literary references, has some value, there is no specific reason to understand those similarities by a sort of direct literary dependence. However, these two books are likely to include the common scribal mindset of the Persian period. Here I put forward shared ideas of God's universal control and freedom which are distinct from the Mosaic covenant and apocalyptic ideas. With these comparisons between Job/Deutero-Isaiah and other concepts in the Hebrew Bible, I propose the dating of the two books and argue that these cultural ideas about God's control and freedom reflect the Persian scribal idea on the formation of the two books.
\end{abstract}

DOI: https://doi.org/10.1515/zaw-2017-0003

Posted at the Zurich Open Repository and Archive, University of Zurich

ZORA URL: https://doi.org/10.5167/uzh-172367

Journal Article

Published Version

Originally published at:

Kwon, Jiseong James (2017). Shared ideas in Job and Deutero-Isaiah. Zeitschrift für die alttestamentliche Wissenschaft, 129(1):32-46.

DOI: https://doi.org/10.1515/zaw-2017-0003 
JiSeong J. Kwon*

\section{Shared Ideas in Job and Deutero-Isaiah}

DOI 10.1515/zaw-2017-0003

\section{Introduction}

Although the literary genres of Job and Deutero-Isaiah (Isaiah 40-55) ${ }^{1}$ have been classified as "wisdom« and "prophecy«, scholars have concluded that they have substantial affinities with common vocabularies, phrases, forms, styles, and themes. ${ }^{2}$ In explaining the origin of affinities, they have suggested the intentional or unintentional use of corresponding texts by biblical writers; e.g., the quotation of Deutero-Isaiah from Job's text (Cheyne, Pfeiffer, Terrien) and in more recent researches the literary quotation or allusion of Job to Deutero-Isaiah (Elliott, Brinks, Kynes).

However, these assumptions of literary reference between the two books have limits in a number of ways. Firstly, the decision of the literary dependence in most cases is based on the relative dating between the two books in which scholars more and less use linguistic characteristics. Representatively, when considering the priority of Job over Deutero-Isaiah, Terrien points out that since the author of Job does not use the Hebrew verb (»to create«) and does not include

1 Although many have assumed that the late redactor of Isaiah 1-55 or the author of DeuteroIsaiah might have added or edited substantial parts of Isaiah 1-39, researches of the relationships between Job and Isaiah until now have only focused on Isaiah 40-55. Thus in this paper, Deutero-Isaiah simply refers to Isaiah 40-55.

2 For various scholarly claims about the comparative study, see the following references; Thomas K. Cheyne, The Prophecies of Isaiah: A New Translation with Commentary and Appendices, vol. 2 (London: Kegan Paul\&Co., 1884), 259-268; Robert H. Pfeiffer, »The Dual Origin of Hebrew Monotheism, «JBL 46 (1927): 193-206; Ralph Elliott, A Comparative Study of Deutero Isaiah and Job (PhD, The Southern Baptist Theological Seminary, Louisville 1956); Samuel L. Terrien, "Quelques Remarques Sur Les Affinités de Job Avec Le Deutéro-Esaïe, « in Volume Du Congrès, Genève, 1965, VTSup 15 (Leiden: Brill, 1966): 295-310; Christina L. Brinks, The Thematic, Stylistic, and Verbal Similarities between Isaiah 40-55 and the Book of Job (ProQuest, UMI Dissertation Publishing, 2011); Will Kynes, »Job and Isaiah 40-55: Intertextualities in Dialogue, « in Reading Job Intertextually, ed. Katharine Dell and Will Kynes, LHB/OTS 574 (New York: T\&T Clark, 2013): 94-105.

*Kontakt: JiSeong James Kwon, University Zürich, Theologische Fakultät, Kirchgasse 9, CH-8001 Zürich, Jiseongjames.kwon@uzh.ch 
the late idea of »vicarious suffering « found in Deutero-Isaiah, there was a literary influence of Job on Duetero-Isaiah. ${ }^{3}$ Similarily, Pfeiffer presents in Job the use of the divine names אלוה and and ack of specific terms (e.g., פעל ,יצר, ברא, related to the subject-matter of »creation«, which may be used in the post-exilic texts and are found in texts of Deutero-Isaiah (Isa 41,4; 44,27; 45,12; 48,13f). ${ }^{4}$ On the other hand, recent commentators have been inclined to accept the late composition of Job in the late $6^{\text {th }}$ or $5^{\text {th }}-4^{\text {th }}$ century BCE, at least not later than $2^{\text {nd }}$ century BCE where Qumran Hebrew texts prove that Job's texts already were in circulation. Based on this late dating of Job, interpreters such as Elliott, Brinks, and Kynes maintain the priority of Deutero-Isaiah over Job.

However, such a definite style and the lack of the doctrine might be no more than possible factors of the early or late $\mathrm{BH}$ profile, with this linguistic data we cannot determine the direction of literary dependence. In fact, the redactional history of the book of Job attests that it was not formed in a specific time, but was produced as an accumulated book from the pre-exilic to the post-exilic period; ${ }^{5}$ although there are obvious reasons to suppose that the prose-tale of Job had already existed in the early period. On the other hand, all that we can say is that Deutero-Isaiah was not earlier than the exilic period and more possibly was formed in the early Persian period. Thus, if the two books went through several redactional and rewritten processes by many authors over the centuries, we may neither readily assume the priority of Deutero-Isaiah over Job nor vice versa. ${ }^{6}$

Secondly, those claiming literary dependence put forth verbal parallels rather than precise analogies between corresponding contexts. For instance, one may submit unique verbal parallels as evidence of the literary relationship between them. Gordis, for example, proposes the unique common phrase, נwho stretched out the heavens alone», which only appears in Job 9,8a and Isa 44,24 (with a small variation) in the Hebrew Bible, and insists that the author of Job directly quotes from Isa 44,24. ${ }^{7}$ But the phrase נטה שמים >to stretch out the heavens « is no more than a prevalent idiom (2Sam 22,10; Ps 18,19; 104,2; 144,5; Jer 10,12; 51,15; Zach 12,1; Isa 42,5; 45,12; 48,13; 51,13.16). Habel holds that this expression is associated with the prevailing Chaoskampf motif and

3 Terrien, »Remarques «.

4 Pfeiffer, »Dual«: 205.

5 Cf. Robert Gordis, The Book of God and Man: A Study of Job (Chicago: University of Chicago, 1978), 207-218; John Gray, The Book of Job, ed. David J. A. Clines (Sheffield: Sheffield Phoenix, 2010), 32-35.

6 Kwon, Scribal, chap. 2.

7 Robert Gordis, The Book of Job: Commentary, New Translation and Special Studies (New York: JTSA, 1978), 103. 
"sacred tent traditions $«{ }^{8}$ More importantly, the same wording conveys different tones and nuances in each context. Deutero-Isaiah in the corresponding context moves to controvert the sceptical view of the divine power found in Job 9,8a. Job's speech (vv. 9,2-4.14-24) about God's power is a lament arising from the frustration, illustrating his inability to dispute with God, while in Isa 44,24, this phrase describes Yahweh who empowers Israelites to recall the greatness of God's power as restorer.

Hence, the claim of the direct dependence between the two books is mostly unpersuasive, with no concrete evidence to support it. Although the adoption of prevalent forms and imageries has often been suggested (Crenshaw, Janzen), this is not different from the former explanations which have proposed an intentional usage of author(s). ${ }^{9}$ Rather than this description of the soure-hunting type, the various resemblances between Job/Deutero-Isaiah and other biblical books - e.g., Genesis, Deuteronomy, Jeremiah and Psalms - may affirm a wide-ranging network of interconnections during the broad period which the two books present.

If it does, in this circumstance of biblical texts and their muti-influences, how can we describe the common similarities or ideas between Job and Deutero-Isaiah? In what sense are those shared ideas in the two books different from other biblical books? I will explain these shared ideas of the two books in comparison of other ideas of the Hebrew Bible, and then will suggest the reasonable dating of Job and Deutero-Isaiah.

\section{Shared Ideas in Job/Deutero-Isaiah and in Ancient Near Eastern Literature}

What Job and Deutero-Isaiah share in the frame of undeserved suffering appears in the common ideas of God's control and freedom. In the two books, God is not described as the One who is working in a local and limited area of Israel, but is seen as universal ${ }^{10}$ over the world and the sovereign Creator among all the creatures. On the one hand, the singleness of God and his incomparable power as the

8 Cf. Norman C. Habel, »He Who Stretches out the Heavens, « CBQ 34 (1972): 34.

9 Cf., e.g., James L. Crenshaw, »Popular Questioning of the Justice of God in Ancient Israel, « ZAW 82 (1970): 380-395 proposes a »prophetic disputation«. For mythological languages, see John G. Janzen, »On the Moral Nature of God's Power: Yahweh and the Sea in Job and Deutero-Isaiah, « CBQ 56 (1994): 458-478.

10 Refer to Robert Davidson, »Universalism in Second Isaiah, « SJT 16 (1963): 166-185; Joel S. Kaminsky and Anne Stewart, „God of All the World: Universalism and Developing Monotheism in Isaiah 40-66, « HTR 99 (2006): 139-163. 
sovereign ruler are highly emphasised in divine control over all creatures and on the other hand, the act of God is not restricted by any rules, such as the moral order and the principle of retribution. Of course, it does not mean that other biblical sources except for Job and Deutero-Isaiah have no idea of God's control over creatures and God's freedom. But they appear more intensively in these two books than in any other biblical texts. The act of God in the two books does not follow traditional rules and principles, but God appears as a sovereign Creator who controls an individual and the universe, and in both books God is an unrestricted and uncontrollable deity in governing the world and the nations. So, my working hypothesis is that these common ideas in the two books are most likely derived from scribal ${ }^{11}$ ideas of the broad Persian period, probably $5^{\text {th }}-4^{\text {th }}$ century BCE before the Hellenistic period.

These common ideas are not exclusively found in the Hebrew Bible, but are prevalent in ancient Near Eastern texts. The fact that scribal culture in the Second Temple period is interacting with and growing up in the diversity of other ancient Near Eastern literatures can be affirmed by the broader knowledge which scribes are likely to possess and develop. There are Mesopotamian and Egyptian literatures which have similarities to examples found in the two books and in this sense those writings were not formed in isolation from other ancient culture. For instance, the form of dialogue in Job is common in Middle Egyptian literature the Debate between a Man and His Soul, The Protests of the Eloquent Peasant, and The Dialogue of Ipuur and the Lord to the Limit - and in Babylonian litearature - Dialogue between a Man and His God, the Babylonian Job, the Babylonian Theodicy, and A Pessimism Dialogue between Master and Servant. ${ }^{12}$ The form of

11 What I propose here as a socio-historical context is that of the literate élite, the so-called "scribes«, who are a small and educated group in the Judean population. This conforms extensively to what Egyptologists and Assyrologists call a scribal class whose literacy functions as a central social mark for the élite. For literacy in cuneiform texts, see A. Leo Oppenheim, »The Position of the Intellectual in Mesopotamian Society, Daedalus 104 (1975): 37-46. For Egyptian literacy, see John Baines, »Literacy and Ancient Egyptian Society, « Man 18 (1983): 572-599. When describing the scribe (ספר) as a biblical writer, it refers to all the educated literate, whether they were trained in the temple, the palace, or the home, and whether later on they had jobs in public institutions, private business, or were unemployed; it is necessary to avoid seeing Hebrew scribes only in the frame of professionalism. See the following references about scribes and scribal culture in the Hebrew Bible. See David M. Carr, Writing on the Tablet of the Heart: Origins of Scripture and Literature (Oxford: Oxford UP, 2005); Karel van der Toorn, Scribal Culture and the Making of the Hebrew Bible (Cambrigde, MA: Harvard UP, 2009).

12 Cf. Karel van der Toorn, »The Ancient Near Eastern Literary Dialogue as a Vehicle of Critical Reflection, « in Dispute Poems and Dialogues in the Ancient and Mediaeval Near East, ed. Gerrit J. Reinink and Herman L. J. Vanstiphout (Louvain: Departement Oriëntalistiek, 1991): 71. 
»self-presentation «, saying »I am X« in Deutero-Isaiah, is prevalent from the Old Babylonian period to the Neo-Assyrian and Neo-Babylonian periods: ${ }^{13}$ e.g., the Zakkur Stela of the early eighth century discovered in the city Hamath of Syria, the Neo-Babylonian source The Cyrus Cylinder, and the Neo-Assyrian oracle Sinqiša-amur of Arbela. Furthermore, these Middle Egyptian texts and Akkadian texts relating to Job and Deutero-Isaiah are mainly bound up with the issues of the undeserved suffering in the individual life, of the experience of abandonment by a deity, and of the national catastrophe and agony; e.g., The Babylonian Job, The Protest of the Eloquent Peasant, The Epic of Keret, and Sumerian Man and His God (Job); The Cyrus Cylinder, The Oracles of Esarhaddon, The Prophecy of Neferti, and The Words of Khakheperreseneb (Deutero-Isaiah).

Although Job and Deutero-Isaiah have many links in form and subject-matter with the early ancient literatures, the scribal idea in terms of the divine-human relationship, seen from a different aspect, is closer to those observed in later foreign texts. We could draw theological affinities between attitudes to a deity in the two books and attitudes to a deity that we find in a number of late foreign texts. For instance, it has been noticed in many comparative studies that Egyptian texts, which are similar to Job and Deutero-Isaiah, mostly come from the Middle Kingdom. However, the theology of the two books, which highlights the notion of a single and powerful god, is much closer to the Ramesside period of the New Kingdom than to the Middle Kingdom. ${ }^{14}$

Further, if we look at late Babylonian literature such as the Sayings of Ahiqar written in an Aramaic papyrus which represents broad Mesopotamian ideas (approximately 500 BCE, though some of this text would possibly be in early $6^{\text {th }}$ or $7^{\text {th }}$ century BCE), one may find a very high idea of the gods controlling the world and an elevated idea of personal piety to a deity. Greenfield notices about the wisdom of Ahiqar that »religious colouring is present throughout, the moral tone is high, and the sentiment that man cannot achieve anything without the approval of god is strong «. ${ }^{15}$ In recent research, Bledsoe states that the story of Ahiqar »confirms the ineffectiveness and futility of human achievement in the

13 Hyacinthe M. Dion, »Le Genre Littéraire Sumérien de L'`hymne À Soi-Même، et Quelques Passages du Deutéro-Isaie, « $R B 74$ (1967): 215-234.

14 Jan Assmann, The Search for God in Ancient Egypt (Ithaca/London: Cornell UP, 2001), 222; John Baines and Elizabeth Frood, »Piety, Change and Display in the New Kingdom, « in Ramesside Studies in Honour of K.A. Kitchen, ed. Mark Collier and Steven R. Snape (Bolton: Rutherford, 2011): $1-17$.

15 Jonas C. Greenfield, »The Wisdom of Ahiqar, « in Wisdom in Ancient Israel: Essays in Honour of J.A. Emerton, ed. John Day, Robert P. Gordon and Hugh G. M. Williamson (Cambridge: Cambridge UP, 1995): 51. 
face of divine power «, that »the gods can be a source of threat, they can also be a source of justice, but the scariest thing for Ahiqar is the inability to know which side of the gods one will face«, and he concludes that the king who performs the divine role as the representative of gods »has absolute power of even mythic proportions that is apparently divinely ordained «. ${ }^{16}$

Therefore, we perhaps suppose that Jewish scribes reflected ancient shared and collective ideas about God and divine-human relationships on producing Job and Deutero-Isaiah. To highlight these distinctive mindsets in the two books, I will present them in prominent contast with the Mosaic covenant which is the traditional concept of God's judgment in Torah/deuteronomistic texts. Common ideas in the two books will be compared with late ideas which usually beongs to the Hellenistic worldview.

\section{The Mosaic Covenant in Job and Deutero-Isaiah}

The theology of Job and Deutero-Isaiah differs from the Mosaic covenantal theology and the principle of God's judgment shown in the Deuteronomistic texts. The Mosaic covenant (cf. Ex 19,5-6; Deut 28,1-14) which is the foundation of the Deuteronomistic worldview portrays a God who behaves in a set of »imposition «, »liability«, and »obligation«. All sufferings and evil in it are interpreted as resulting from individual and communal misbehaviour, and whenever Israelites return to their deity in the midst of God's wrath by keeping the Torah, their God will restore the breached relationship with blessings and rewards. In this regard, although it might be supposed that this central idea of Mosaic covenant presumably could be an assumed belief in Job and Deutero-Isaiah, they do not sustain the orthodox view of the Mosaic covenant or the deuteronomistic covenant, as it is. The question is: "Do they affirm and encourage the deuteronomistic view, that the obedience of law brings blessings and the rejection of law brings curses and suffering, and the view of the moral order or the retributive principle that the pious succeeds and the wicked perishes?«

16 Seth A. Bledsoe, Wisdom in Distress: A Literary and Socio-Historical Approach to the Aramaic Book of Ahiqar (The Florida State University: PhD, 2015): 326; 351; 373. 


\subsection{Job}

Let us see whether the book of Job supports the covenantal relationship between individuals and God.

Firstly, the view of the book of Job in terms of the cause of suffering of an innocent individual differs from the belief of God's judgment indicated by Deuteronomistic texts. On the one hand, the loss and agony of an individual, and then the consequent blessing and restoration in the prose-tale might sustain the principle of retribution and the Mosaic covenant. ${ }^{17}$ It is not a coincidence that the prologue of Job begins with the the link between the piety of the God-fearing, blameless, and rightous man (vv. 1,1.8; 2,3) and his external prosperity, and that the epilogue states the reversal of the unfortunate status. This may imply the retributive principle of blessings and cursings. However, why God ordained that an innocent Job should suffer is not stated in the framework of the moral order. ${ }^{18}$ The text simply says that his suffering was "without cause» or "without purpose« (םח (IV) vv. 2,3; 9,7) which would mean an accidental event. It seems, that if anything, ironically it was none other than Job's piety which led to his extreme suffering (vv. 1,8; 2,3). This makes a contrast with the Deuteronomistic worldview of God's judgment concerning human sinfulness. ${ }^{19}$ Some may claim that in the epilogue, the doubling of Job's estate means that Yahweh blessed him because of his great patience and that this affirms the Deuteronomistic covenant (v. 42,10). However, his dead children are not brought back to life and what the most pious man experienced itself somewhat undermines the retribution theology in the Mosaic covenant.

Secondly, the view of Job's friends about God's judgment and retribution is challenged by Job's questions about inexplicable suffering and God's justice. On the one hand, the speeches of Job's friends are analogous to the traditional understanding of blessings and cursings which the Deteronomistic theology supports, though it is hard to prove that the author of Job used Deuteronomy as a reference book. According to Job's friends, human misbehaviours and disobedience to laws bring retributive punishment to humans, so that individual suffering is bound to

17 For example, Max Rogland, »The Covenant in the Book of Job, «TR 7 (2009): 49-62.

18 David J. A. Clines, »Deconstructing the Book of Job, « in What Does Eve Do to Help?: And Other Readerly Questions to the Old Testament, ed. David J. A. Clines, JSOTSup 94 (Sheffield: JSOT, 1990): 106-123 argues that the book of Job »marginalizes « the doctrine of retribution.

19 Similar to this view, Markus Witte, »Does the Torah Keep Its Promise? Job’s Critical Intertextual Dialogue with Deuteronomy, « in Reading Job Intertextually, ed. Katharine Dell and Will Kynes, LHB/OTS 574 (New York: T\&T Clark, 2013): 65 claims that the book of Job »may be read as a critical commentary on Deuteronomy«. 
be the consequence of individual sins against God (vv. 4,6-11; 5,1-7; 8,3-4.11-19; $15,20-35 ; 22,4-11)$. And religious piety through obedience to laws and good deeds deservedly produces a satisfactory result of divine favour and blessing (vv. 5,1726; 8,5-7; 22,21-30).

On the other hand, Job in the dialogue, partially agrees with the classical view of divine judgment which Job's friends claim, while in the prologue Job does not deny a foundational belief in the God of moral order. Nevertheless, as time passes, Job expresses his frustration and doubt about God's justice. Job's suffering, as such, attests that that dogma is full of defects when explaining the relation between suffering and judgment. ${ }^{20}$ Disasters which he encountered led him to become convinced that there is little association between human misbehaviour and suffering. Firstly, Job claims that suffering is not the retributive act for individual sins (vv. 6,29-30; 10,7; 27,1-6). Human suffering in many cases cannot be explained by the friends' orthodox belief and cannot be the consequence of individual sin. Secondly, divine protection and security are not always given to the righteous who seek God and whose vindication seems to be far off (vv. 19,7; 17,3; 23,8-9; 28). Instead, Job sees that there could be potential mistakes in God's judgment and that much of the moral order in the world could have collapsed. In this way, two divergent views on the divine judgment show the glaring disparity between the ideal of retributive theology and the reality of injustice.

Thirdly, Yahweh's speech has no special association with the Mosaic covenant or the moral order. Yahweh's rebuke in 38,2 is that Job does not have the understanding necessary to direct the universe along the right track, and the entire speech, which highlights how marvellously Yahweh controls the world, plays a significant role in rebuking Job's misunderstanding of divine design (עצה; v. 2). In it, we cannot find any reference of human suffering and injustice in the world, and no attempt to defend the accusation of injustice raised in the dialogue. The description of the beauty of two symbolic beasts, Behemoth and Leviathan in Yahweh's second speech (vv. 40,15-41,26 [Eng. 40,15-41,34]) states the nature of divine freedom by showing their fearful and glorious characteristics in relation to humans. Just as humans cannot control the beasts, Yahweh cannot be tamed by humans (vv. 41,4.7-9), so much so that humans' endeavours to manipulate and to resist God would be absurd (vv. 41,2-3 [Eng. 41,10-11]). Interestingly, in the description of beasts, Yahweh calls for the possibility of imposing responsibilities on Leviathan, as required in the obligatory relation: »Will he make a covenant

20 The failure of the friends is finally confirmed in the epilogue (Job 42,7-8). The defect of the conventional theology defended by the friends is judged and condemned by God as »folly« (v. 8), in that the friends did not say "what is right « about Job's innocence and God's judgment; on the contrary, Job’s piety is reaffirmed as God calls Job »my servant« (vv. 7-8). 
(ברית) with you to be taken as your perpetual slave?« (v. 40,28 [Eng. 41,4]). If Job has no ability to discipline Leviathan by making a »covenant«, their Creator God will absolutely not be influenced, nor cajoled, by human intercession. In this sense, Yahweh is portrayed as being unconstrained by any obligations, justice, or impositions by any sort of religious laws (vv. 41,1.10-11).

\subsection{Deutero-Isaiah}

In Deutero-Isaiah, the divine judgment against Jacob-Israel is partially described in the principle of retribution as the consequence of sins, as general prophetic literature notices (Isa 42,18-25; 43,22-28; 50,1-3). Nevertheless, the concept of God's justice and judgment in Deutero-Isaiah is different from the principle shown in the Mosaic covenant. In fact, Deutero-Isaiah hardly mentions the Mosaic covenant, although there are considerable verbal similarities with Deuteronomy and Exodus. Anderson, in analysing the term »torah" in Deutero-Isaiah, maintains that in any case, there is no clear allusion »to Moses, the Sinai theophany, the decalogue, or the conditional covenant $« .{ }^{21}$ Of course, there are references to the Hebrew word ברית (»covenant«); in Isa 42,6 and 49,8 (»a covenant for the people $\lll)$, 54,9-10 (»Noah«), and 55,3 (»David«). However, none of them is associated ברית , עולם חסדי דוד הנאמנים עan eternal covenant, the faithful mercies to David (vv. $55,3 \mathrm{~b}$ ), is not intended to refer to the rehabilitation of the Davidic family and successors (cf. Ps 89,31-34; 132,11-12; 2Sam 7,14-15) and the reference to the Davidic covenant certainly implies the sense of the new covenant (Isa 42,6; 49,8) which involves the extension to all nations as well as to the whole people of Israel. ${ }^{22}$ There are several aspects to evince that the scribal ideas of divine control and freedom in Deutero-Isaiah diverge from the Mosaic covenant.

Firstly, the God of Israel in Deutero-Isaiah appears free from any covenantal bonds and rules that require obligations (vv. 42,6; 49,8; 54,10; 55,3). When supposing why sufferings come to Israel, can we say they all result from the sins of

21 Bernhard W. Anderson, »Exodus and Covenant in Second Isaiah and Prophetic Tradition," in Magnalia Dei, the Mighty Acts of God: Essays on the Bible and Archaeology in Memory of G. Ernest Wright, ed. Frank M. Cross, Werner E. Lemke and Patrick D. Miller (New York: Doubleday, 1976): 341.

22 Scott Hahn, »Covenant in the Old and New Testaments: Some Current Research (1994-2004), « CBR 3 (2005): 277. Hugh G. M. Williamson, Variations on a Theme: King, Messiah and Servant in the Book of Isaiah, Didsbury Lectures 1997 (Carlisle: Paternoster, 1998), 177 notices that "the covenant with David is here potentially transferred to the people as a whole«. 
Israel? Deutero-Isaiah speaks that the present sufferings partly are not the consequence of divine punishment of their iniquities, and that, in some cases, the Israelites received punishment greater than they should pay; כפלים בכל־חטאתיה »double for all her sins « (v. 40,2); it is the view of the exiled Israelites that they are being overly punished. This is indicated in their complaints and laments where the statement - »My way is hidden from Yahweh and my justice is ignored by my God« (v. 40,27b) - evinces that God's verdict on their behaviours is unfair (cf. vv. 40,2; 49,14). Furthermore, the great suffering of Israel which is portrayed in the imagery of Yahweh's servant ${ }^{23}$ is, as generally people believed, not caused by divine condemnation in consequence of her own sins (vv. 53,1-3). She accepted all the sufferings and even death for the divine purposes which is demanded by God in order to purify people and remove their transgressions (vv. 53,4-6.10-11). The cause of those sufferings even coming to death is her innocence itself, and this severely undermines the law system in Leviticus (v. 53,10).

Secondly, the God of Israel is sovereign and free to act in Israel's deliverance. Let us consider why the restoration of Israel occurs. Deutero-Isaiah begins with the declaration of the end of God's wrath towards Jacob-Israel (v. 40,1) and with the good news of »comfort« (v. 40,9). If so, are the promises of forgiveness and restoration given to them as the reward of their good deeds? Ironically, while Deutero-Isaiah obviously spells out their sins and punishment (vv. 43,22-24.28), the prophet emphasises that Yahweh's sovereign power, not the covenant-based promise, will forgive their wrongdoings (v. 43,25). Their restoration is regarded as independent of human behaviour, not as a reward for their return to obedience. The obedience of Israel is in no way the certain reason of their restoration (vv. 41,20; 43,25; 50,1).

Thirdly, the God of Israel is described not as a local deity committed to a particular group, but as the cosmic God for all the nations on the earth (vv. 45,22-25). ${ }^{24}$ Of course, the distinctive role of Israel among nations is exemplified in the mission of Yahweh's servant as »a light to the nations « (v. 49,6) and »a covenant for the people« (vv. 42,6; 49,8). However, God's ultimate purpose in Deutero-Isaiah is not restricted to an ethnic and geographical sphere, but is expanded to the cosmic community who will follow and worship Yahweh (v. 45,24a). In fact, from

23 Interpreters have proposed various arguments about the identity of this Servant (Isa 52,1353,12 ). Although it is hard to determine this figure as Jacob-Israel, in the given passages it is a better understanding to see him as Israel rather than a third individual or the prophet. Cf. John Goldingay, The Message of Isaiah 40-55: A Literary-Theological Commentary (London: T\&T Clark, 2005), 473-477.

24 Cf. Julian Morgenstern, »Deutero-Isaiah’s Terminology for `Universal God», JBL 62 (1943): 269-280. 
the beginning of Isa 40, it has already been announced that Yahweh's glory will be revealed to »all flesh « (v. 40,5). In this universalistic vision, divine justice and righteousness are depicted as open to the new community who listens to Yahweh's message (vv. 51,4-6.22), not only for Jacob-Israel.

\section{Late Ideas in Job and Deutero-Isaiah}

Next, the late notions in Daniel and Ecclesiastes are differentiated from such a notion of divine control in Job and Deutero-Isaiah. Firstly, in general apocalyptic literature like the book of Daniel as a distinct genre of writing has the idea of a fixed plan of the future history and this belongs to the Hellenistic period. ${ }^{25}$ The idea of divine control in Deutero-Isaiah and Job shows neither such a strong symbolic language as that in apocalyptic literature nor a deterministic idea of a final judgment; God is not managing the world with a fixed timeline to achieve God's future plan. The idea of planning for the future in the genre of apocalypse is not found until the Hellenistic period; e.g., Daniel, 1 Enoch, 2 Enoch, 4 Ezra, and 2 Apocalypse of Baruch.

The book of Daniel is strongly tied up with the religious impositions on the Jews and the ethical obligations that they have to God - food laws (Dan 1,8), the rejection of idolatry (v. 3,18), and regular prayer (v. 6,10) - and urges them to commit themselves to the God of Israel. ${ }^{26}$ However, we should distinguish the concept of »Torah-piety ${ }^{27}$ in the Hellenistic period from the early idea of the Deuteronomistic covenant. The notion of Israel's history in Dan 9 is tied up with a further apocalyptic worldview and this is a solid development of personal piety going hand in hand with the idea of divine plan. Of course, there might be a little space inside the fixed plan which pious people may change through prayers and obedient behaviour. However, the idea of a divine plan would not come into being as the result of prayer which might be theologically problematic (vv. 9,1-23), but rather from that point onwards, all humans are acting according to the divine plan which they cannot see and fully comprehend.

25 John J. Collins, The Apocalyptic Vision of the Book of Daniel, HSM 16 (Missoula: Scholars, 1977), 30; 32.

26 John Barton, »Theological Ethics in Daniel, « in The Book of Daniel: Composition and Reception, ed. John Joseph Collins and Peter W. Flint, VTSup 83 (Leiden: Brill, 2001): 662.

27 See the section, 6.3 »Die Torah-Frömmigkeit« from Rainer Albertz, Religionsgeschichte Israels in alttestamentlicher Zeit, Grundrisse zum Alten Testament 8/2 (Göttingen: Vandenhoeck \& Ruprecht, 1992), 623-633. 
Furthermore, the book of Ecclesiastes in general has been regarded as having the broad influence of Greek literature, ${ }^{28}$ and at least, it seems to include a salient idea, »the subordination of human actions to much greater processes «; ${ }^{29}$ one might call this so-called »determinism «; ${ }^{30}$ nevertheless, the Hebrew Bible hardly supports Stoic determinism, and such a philosophical idea is totally different from the simple reactions to human behaviour shown in Job and Deutero-Isaiah (Koh 12,13-14). ${ }^{31}$ God controls the pleasure of eating and drinking (v. 2,24), wealth and possession (v. 5,19), and human behaviour (vv. 9,1-2). The passage of Koh 3,1-15 emphasises the »appointed time« (עת) for every business (לכל־חפץ) and for human feelings which are controlled by God, and highlights God's acts which cannot be changed by humans (vv. 3,11.14). These do not usually emerge from the Persian scribal idea, while Deutero-Isaiah and Job have neither such a strong symbolic language nor a deterministic idea of a final judgment. Moreover, Ecclesiastes, like Job, shows little interest in the Mosaic covenant of retribution and reward. Although the author seems to be obliged to adopt the idea of judgment because of the general assumption in the context of Israelite literature, God's judgment in this life is delayed and justice to the wicked is not executed (vv. 8,11-12a). The concept of God's judgment in Ecclesiastes gets entangled in a fixed time and event which is already predestined (vv. 3,17; 10,8; 11,9b).

\section{Summary and Conclusion}

Although Job and Deutero-Isaiah are classified as having the specific social contexts for different types of compositions, they indicate similar ideas about human-divine relationship and reflect universal and powerful Creator over crea-

28 e.g., John Gammie, »Stoicism and Anti-Stoicism in Qoheleth, «Hebrew Annual Review 9 (1985): 169; Otto Kaiser, »Determination und Freiheit beim Kohelet/Prediger Salomo und in der Frühen Stoa, « Neue Zeitschrift für Systematische Theologie und Religionsphilosophie 31/3 (1989): 251-270; Joseph Blenkinsopp, »Ecclesiastes 3:1-15: Another Interpretation, «JSOT 66 (1995): 55-64.

29 Stuart Weeks, Ecclesiastes and Scepticism, LHB/OTS 541 (New York: T\&T Clark, 2012), 75.

30 Dominic Rudman, «Determinism and Anti-Determinism in the Book of Koheleth, «JBQ 30 (2002): 97 defines it as »the belief that human thought, action, and feeling is, to a greater or lesser extent, controlled by a greater power and that human beings have little or no free will of their own «.

31 If there is »determinism« in Ecclesiastes, one could say that the book of Proverbs also has this idea (cf. Prov 16,1.4; Koh 9,7). Stuart Weeks, Scepticism, 152-159 definitely avoids using this term. Here, in order to emphasise the difference of Ecclesiastes from Job, I would often employ »deterministic« or »determinism« for convenience, but this should be distinguished from Greek determinism. 
tures. What do these discrepancies and differences among texts attest about scribal culture and the historical development of the biblical texts? On the one hand, while the texts of Job and Deutero-Isaiah do not support a traditional idea of the Mosaic covenant, other scribal texts do subscribe to the idea of covenant. To some degree, it has been agreed that the earlier edition of Deuteronomy possibly has been dated to the pre-exilic period and that its exilic edition has been written in the reflection of the destruction of Jerusalem; ${ }^{32}$ the "Covenant Code" in Ex 20,22-23,33 which covers Deuteronomy has been treated as the earliest form of biblical law. If the dating of Deuteronomy is acceptable in this comparison, the strong concern in terms of God as the sovereign and universal Creator is more likely to be closer to the Persian scribal thoughts than to pre-exilic and exilic scribal ideas. However, this does not imply that there were no ideas to support the Deuteronomistic covenant and law in the post-exilic period, but Deuteronomy and the Deuteronomistic history were distributed and revised throughout the Second Temple period. However, what we confirm is that the critical reception of the retribution theology emphasised in the Mosaic covenant in Job and the notion of the new covenant in Deutero-Isaiah would not be found until the Persian period. For instance, although the texts of Jeremiah, Ezekiel, and Prov 1-9 show various similarities with the Deuteronomistic text and more or less support its theology, they possibly adapt and reinterpret the Mosaic covenant in a new context throughout the experience of Exile.

On the other hand, given that those texts of the Hellenistic period originate from a group of scribes, what consequences can we deduct from the fact that Deutero-Isaiah and Job have little concept of God's plan and a deterministic idea, though the later texts such as Daniel and Ecclesiastes have it? If the dating of the books of Daniel and Ecclesiastes are agreed as the Hellenistic period, Job and Deutero-Isaiah would be more attuned to the earlier texts in the Persian period than those of the Hellenistic period. ${ }^{33}$

32 Cf. Rainer Albertz, Israel in Exile: The History and Literature of the Sixth Century B.C.E., SBL 3 (Atlanta: SBL, 2003).

33 However, considering the theory of a late redaction of the book of Job, some might not be satisfied with this conconlusion of this dating. Gray, Job, 35 supposes that the Elihu section and "the poems on Behemoth and Leviathan, and 42.12ff « "as a midrashic expansion" are the later addition. In particular, Harald M. Wahl, Der Gerechte Schöpfer: eine redaktions- und theologiegeschichtliche Untersuchung der Elihureden, Hiob 32-37, BZAW 207 (Berlin: De Gruyter, 1993) argues that Elihu speech was added in $3^{\text {rd }}$ century BCE as a bridge section between Job's monologue and Yahweh's speech. Also, refer to Markus Witte, "Job in Conversation with the Torah, « in Wisdom and Torah, ed. Bernd U. Schipper and David A. Teeter, JSJSup 163 (Leiden: Brill, 2013): 96. Nonetheless, it remains still unresolved why the redactor of Elihu missed the name of Elihu in prose-tale. See David J. A. Clines, Job 1-20, WBC 17 (Dallas: Word Books, 1989), LVIII-LIX. Of 
Accordingly, those diversities and discrepancies among scribal texts can be important to the understanding of the history of the development of scribal thought. Job and Deutero-Isaiah most likely reflect scribal ideas between the critical reception of the Mosaic covenant and the rise of an apocalyptic worldview. This notices that there is a dynamic shift in scribal concerns from a view of a national God who rules Israel by laws and a covenant to a high view of the God of Israel as a powerful and universal deity.

Zusammenfassung: Mit Verweis auf sprachliche und inhaltliche Gemeinsamkeiten zwischen den Büchern Hiob und Deuterojesaja (Jes 40-55) wurde behauptet, dass es eine literarische Abhängigkeit gebe oder das eine Buch das andere beeinflusst habe. Trotz des Wertes eines solchen autorenorientierten Ansatzes gibt es keinen Grund solche Ähnlichkeiten durch eine direkte literarische Abhängigkeit zu erklären. Wahrscheinlich teilen diese Bücher allerdings die gemeinsame Denkweise der Schreiber in der Perserzeit. Dazu schlage ich geteilte Vorstellungen einer universalen Kontrolle durch Gott und Freiheit vor, die sich vom mosaischen Bund und apokalyptischen Ideen unterscheiden. Auf dem Hintergrund dieses Vergleichs zwischen Hiob/Deuterjesaja und anderen Konzepten der Hebräischen Bibel schlage ich eine Datierung der beiden Bücher vor und behaupte, dass diese kulturellen Vorstellungen göttlicher Kontrolle und Freiheit die Vorstellungen der Schreiber zur Zeit der Entstehung der Bücher widerspiegeln.

Abstract: It has been suggested that the books of Job and of Deutero-Isaiah (Isaiah 40-55) have a variety of similarities in their linguistic features and common subject-matter and because of this, it has been argued that there is literary dependence or influence of one book upon the other. Although such an author-oriented

course, Elihu's claim does not seem to be dissimilar from Job's three friends who incessantly condemn Job's sin (Job 34,35-37), and affirms the divine justice as divine retribution in some ways (Job 37,23), even though Elihu even adds several novel ideas in terms of ways of the divine communication through dream and experience (Job 33,14-28). However, this cannot be any reasons to agree a late redaction of the book. Elihu is speaking in the inheritance of traditional wisdom circle and in the lack of understanding the new dimension of human suffering. Further, Elihu's statement about God's vastness in Job 36-37 certainly lead readers to Yahweh's speeches. Indeed, the convergence "with the theology of Deuteronomy" does not necessarily mean that the redactor of Elihu speech edited this part in the Hellenistic period. Edwin M. Good, In Turns of Tempest: Reading of Job, with a Translation (Stanford: Stanford UP, 1998), $4 \mathrm{f}$. supposes that while we cannot specify the written date of this book, Job »took its present form after the Babylonian Exile«; Choon-Leong Seow, Job 1-21: Interpretation and Commentary (Grand Rapids, MI: Eerdmans, 2013), 31-38 maintains that the dialogue of Elihu and Yahweh's speeches are not the secondary addition by late editors, but are part of original composition. 
approach, by which scholars explain similarities by the theory of literary references, has some value, there is no specific reason to understand those similarities by a sort of direct literary dependence. However, these two books are likely to include the common scribal mindset of the Persian period. Here I put forward shared ideas of God's universal control and freedom which are distinct from the Mosaic covenant and apocalyptic ideas. With these comparisons between Job/ Deutero-Isaiah and other concepts in the Hebrew Bible, I propose the dating of the two books and argue that these cultural ideas about God's control and freedom reflect the Persian scribal idea on the formation of the two books.

Résumé: L’observation de nombreuses similitudes linguistiques et thématiques entre les livres de Job et du Deutéro-Esaïe (Esaïe 40-55) ont induit l'idée d'une dépendance ou influence littéraire d'un livre sur l'autre. Bien qu'une telle approche, par laquelle les chercheurs expliquent les similitudes par la théorie de dépendences littéraires, se justifie, elle ne s'impose pas. Les deux livres reflètent vraisemblablement la même mentalité de certains scribes de l'époque perse. L'auteur souligne les idées partagées du contrôle universel et de la liberté divine, distincts de l'alliance mosaïque et des idées apocalyptiques. A partir de ces comparaisons entre les livres de Job et du Deutéro-Esaïe et d'autres concepts de la Bible hébraïque, il propose de dater les deux livres à la même époque et défend l'idée que ces idées culturelles sur le contrôle et la liberté de Dieu reflètent une compréhension perse des scribes au niveau de la formation des deux livres.

Article Note: This article refers to and summarizes the content (esp. chapter 6) of JiSeong J. Kwon, Scribal Culture and Intertextuality: Literary and Historical Relationships between Job and Deutero-Isaiah, FAT II 85 (Berlin: Mohr Siebeck, 2016). 